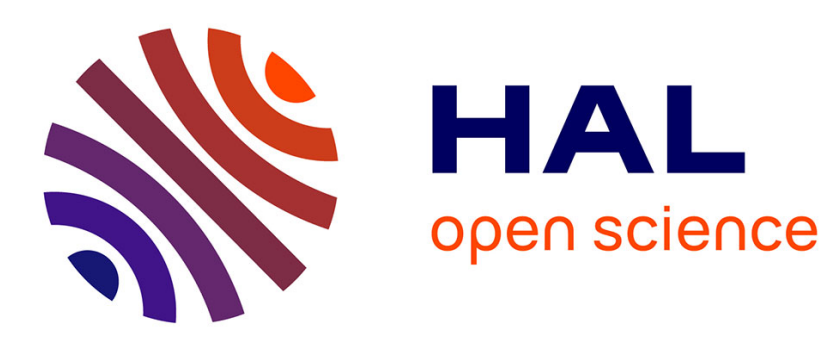

\title{
Rating the blood pressure outcome after adrenalectomy for unilateral primary aldosteronism
}

\author{
Olivier Steichen
}

\section{To cite this version:}

Olivier Steichen. Rating the blood pressure outcome after adrenalectomy for unilateral primary aldosteronism. The Lancet. Diabetes \& Endocrinology , 2017, 5 (9), pp.670-671. 10.1016/S22138587(17)30180-8 . hal-02503412

\section{HAL Id: hal-02503412 \\ https://hal.sorbonne-universite.fr/hal-02503412}

Submitted on 9 Mar 2020

HAL is a multi-disciplinary open access archive for the deposit and dissemination of scientific research documents, whether they are published or not. The documents may come from teaching and research institutions in France or abroad, or from public or private research centers.
L'archive ouverte pluridisciplinaire HAL, est destinée au dépôt et à la diffusion de documents scientifiques de niveau recherche, publiés ou non, émanant des établissements d'enseignement et de recherche français ou étrangers, des laboratoires publics ou privés. 
Rating the blood pressure outcome after adrenalectomy for unilateral primary aldosteronism

Olivier Steichen

AP-HP, Tenon hospital, Internal medicine department, F-75020 Paris, France;

Sorbonne Universités, UPMC Université Paris 06, INSERM, LIMICS, F-75005 Paris, France.

Correspondence to: Olivier Steichen

Hôpital Tenon, Service de Médecine Interne,

4 Rue de la Chine, 75020 Paris, France

Tel.: (+33/0) 1560178 31; Fax: (+33/0) 1/56 017082

E-mail: olivier.steichen@aphp.fr 
Primary aldosteronism (PA) if defined by autonomous aldosterone hypersecretion, which almost invariably leads to high blood pressure (BP) and sometimes to hypokalemia. PA also induces cardiovascular and kidney damage partly independent from BP increase (1). When aldosterone hypersecretion originates from a single adrenal, it can be cured by unilateral adrenalectomy. Plasma aldosterone and potassium concentrations are expected to normalise and BP to decrease postoperatively. The normalisation of aldosterone secretion should also prevent further BP independent target organ damage and may even reverse it (2-4).

From the patient perspective, the immediate benefits of adrenalectomy are a better BP control, a decrease in the medication burden, or both. However, high BP is cured in only about $40 \%$ of cases, with a wide variability across published series (5). Estimates of BP improvement are even more heterogeneous, due to the lack of a consensual definition integrating both postoperative BP and medication changes (5). The Primary Aldosteronism Surgery Outcome (PASO) investigators have performed an impressive collaborative work to standardise postoperative assessment and to show the value of using uniform criteria across case series.

They have set up an international and multidisciplinary panel of 31 experts (including endocrinologists, surgeons, internists, cardiologists, nephrologists), who reached consensual definitions of postoperative biochemical and blood pressure outcomes, distinguishing cure and improvement. They have then used these criteria to assess postoperative outcomes in retrospective case series from 12 centres totalling 705 patients. Overall, they found a 37\% hypertension cure rate and a further $47 \%$ improvement rate, both with a wide variability across series. Finally, they have shown that sex and age were strongly associated with the BP outcome at the patient level and that the age and sex case-mix explained a significant part of BP outcome variability across centres.

Nonetheless, several caveats must be addressed. First, labelling the lack of significant postoperative decrease in BP or medication as clinical failure is a misnomer, because the benefit on target organs is partly independent of BP. Focusing on BP and medication changes may just be scratching the surface of clinical benefit.

Second, the PASO investigators refer only to office BP measurements to define BP improvement, probably because the case series used to validate the criteria were collected at times when out-of-office BP measurements were not yet regarded as best practice. However, patients now undergoing adrenalectomy for unilateral PA should be assessed with out-of office BP measurements $(6,7)$. This is especially important for research purposes and up-todate outcome criteria should include out-of-office BP thresholds.

Third, the PASO criteria promote a categorical assessment of the BP outcome of adrenalectomy and restrict complete clinical success to hypertension cure. However, the BP dependent clinical benefits depend on the magnitude of BP decrease rather than crossing the BP threshold that currently defines hypertension. For example, patient 2 from the Table is classified as improved only whereas he probably derives a greater clinical benefit from his very large BP decrease than patient 1 , who is cured but with a much smaller BP decrease.

Generally, patients with higher blood pressure are more likely to experience a large postoperative decrease in $\mathrm{BP}$ and therefore more likely to meet the criteria of partial clinical success, but they are less likely to be completely cured. This explains the apparent paradox that higher systolic BP and higher medication load are negatively associated with 
hypertension cure but positively associated with hypertension improvement, in the PASO study as well as in previous studies $(5,8)$.

Fourth, the $20 \mathrm{mmHg}$ systolic BP decrease used to define BP improvement probably surpasses the 0.5 daily-defined doses (DDD) decrease used for the same purpose. This leads to contra-intuitive consequences. For example, patient 3 from the Table is classified as cured and patient 4 as failure although their BP benefit is exactly the same and can be regarded as clinically significant.

Limited evidence in patients with PA suggests that dropping one antihypertensive drug class matches a $5 \mathrm{mmHg}$ decrease in systolic BP (8). Strong evidence from large placebocontrolled studies in patients with essential hypertension matches $0.5 \mathrm{DDD}$ with $7 \mathrm{mmHg}$ systolic BP (9). Moreover, the relation between DDD and BP changes is not simple. For example, two medications at half dose add up to 1 DDD but decrease BP about 50\% more than one medication at full dose that also represents 1 DDD (9). Finally, 1 DDD of mineralocorticoïd receptor antagonist probably differs from 1 DDD of non specific antihypertensive medication in patients with PA.

While there is probably room for improvements in future revisions, the PASO criteria mark a significant advancement for the study of postoperative outcomes in PA. They should inspire similar and maybe joint efforts to standardise BP outcome assessment of other nonpharmacological interventions, like revascularisation for renal artery stenosis, bariatric surgery for morbid obesity, and renal denervation or carotid baroreceptor stimulation for resistant hypertension.

\section{Conflict of interest}

The author declared no conflicts of interest 


\section{References}

1. Savard S, Amar L, Plouin P-F, Steichen O. Cardiovascular complications associated with primary aldosteronism: a controlled cross-sectional study. Hypertension. 2013 Aug;62(2):331-6.

2. Catena C, Colussi G, Nadalini E, Chiuch A, Baroselli S, Lapenna R, et al. Cardiovascular outcomes in patients with primary aldosteronism after treatment. Arch Intern Med. 2008 Jan 14;168(1):80-5.

3. Lin Y-H, Lin L-Y, Chen A, Wu X-M, Lee J-K, Su T-C, et al. Adrenalectomy improves increased carotid intima-media thickness and arterial stiffness in patients with aldosterone producing adenoma. Atherosclerosis. 2012 Mar;221(1):154-9.

4. Marzano L, Colussi G, Sechi LA, Catena C. Adrenalectomy Is Comparable With Medical Treatment for Reduction of Left Ventricular Mass in Primary Aldosteronism: MetaAnalysis of Long-Term Studies. Am J Hypertens. 2014 Oct 21;

5. Steichen O, Zinzindohoué F, Plouin P-F, Amar L. Outcomes of adrenalectomy in patients with unilateral primary aldosteronism: a review. Horm Metab Res Horm Stoffwechselforschung Horm Métabolisme. 2012 Mar;44(3):221-7.

6. Pickering TG, Miller NH, Ogedegbe G, Krakoff LR, Artinian NT, Goff D, et al. Call to action on use and reimbursement for home blood pressure monitoring: executive summary: a joint scientific statement from the American Heart Association, American Society Of Hypertension, and Preventive Cardiovascular Nurses Association. Hypertens Dallas Tex 1979. 2008 Jul;52(1):1-9.

7. O'Brien E, Parati G, Stergiou G, Asmar R, Beilin L, Bilo G, et al. European Society of Hypertension position paper on ambulatory blood pressure monitoring. J Hypertens. 2013 Sep;31(9):1731-68.

8. van der Linden P, Steichen O, Zinzindohoué F, Plouin P-F. Blood pressure and medication changes following adrenalectomy for unilateral primary aldosteronism: a follow-up study. J Hypertens. 2012 Apr;30(4):761-9.

9. Law MR, Wald NJ, Morris JK, Jordan RE. Value of low dose combination treatment with blood pressure lowering drugs: analysis of 354 randomised trials. BMJ. 2003 Jun 28;326(7404):1427. 
Table. Examples of blood pressure outcome categorisation according to the PASO criteria

\begin{tabular}{|c|c|c|c|c|c|c|c|}
\hline & \multicolumn{2}{|l|}{ Preoperative } & \multicolumn{2}{|c|}{ Postoperative } & \multicolumn{2}{|c|}{ Change } & \\
\hline Patient & medication (mg) & $\mathrm{BP}(\mathrm{mmHg})$ & medication (mg) & $\mathrm{BP}(\mathrm{mmHg})$ & medication & systolic BP & BP outcome \\
\hline 1 & diltiazem 240 & $132 / 79$ & none & $126 / 75$ & -1 DDD & $-6 \mathrm{mmHg}$ & cure \\
\hline 2 & $\begin{array}{l}\text { irbesartan } 300 \\
\text { bisoprolol } 2.5 \\
\text { hydrochlorothiazide } 6.25 \\
\text { felodipine } 5\end{array}$ & $189 / 109$ & none & $144 / 102$ & - 3.5 DDD & - $45 \mathrm{mmHg}$ & improvement \\
\hline 3 & spironolactone 25 & $148 / 93$ & none & $134 / 88$ & - 0.33 DDD & $-14 \mathrm{mmHg}$ & cure \\
\hline 4 & $\begin{array}{l}\text { spironolactone } 25 \\
\text { amlodipine } 5\end{array}$ & $148 / 93$ & amlodipine 5 & $134 / 88$ & - 0.33 DDD & $-14 \mathrm{mmHg}$ & failure \\
\hline
\end{tabular}

BP: blood pressure

DDD: daily-defined dosis 